\title{
TOXICOLOGICAL AND BIOCHEMICAL ACTIVITIES OF FATTY ACIDS AGAINST EARIAS INSULANA (BOISD.)( LEPIDOPTERA : NOCTUIDAE)
}

\author{
HEMAT Z. MOUSTAFA ${ }^{1}$, HEBA YOUSEF ${ }^{1,2}$ and SAHEIR F. EL-LAKWAH ${ }^{1}$
}

\author{
1 Plant Protection Res. Institute, ARC, Giza, Egypt. \\ ${ }^{2}$ Chemistry Department, Faculty of Sciences and Arts, University of Jeddah, Khulais, \\ Jeddah, Saudi Arabia. \\ Author for corresponding: hemat.zakaria@gmail.com, hebayousef2004@yahoo.com
}

(Manuscript received 18 February 2018)

\begin{abstract}
$\mathrm{T}$ he activity of three $\mathrm{C} 18$ fatty acids (oleic, stearic and linoleic acids) was conducted under laboratory conditions on $1^{\text {st }}$ instar larvae of spiny bollworm, Earias insulana (Biosd.). The results showed that oleic and stearic acid were more effective than linoleic acid with different concentrations. Results of the latent effect of $\mathrm{LC}_{50}$ concentrations for the three tested fatty acids showed that all the acids elongate the larval \& pupal period than control of SBW. Furthermore, stearic acid introduce the shortest larval and pupal duration (18.93days and10.19 days, respectively) than the other two tested acids. Studying biochemical and enzymatic activities in the resulted $4^{\text {th }}$ instar larvae of $E$. insulana after treatment with the $\mathrm{LC}_{50}$ concentration cleared that linoleic acid recorded increasing in total protein content (46.93\%). In contrast, oleic and stearic acid showed reduction (-28.49\&-1.96, respectively). Total carbohydrates and total lipids contents decreased in the three treatments compared to the control. The highest decrease in carbohydrates content recorded in oleic acid treatment $(-31.37 \%)$ while, stearic acid recorded the highest decrease in total lipids content $(-35.29 \%)$. Also, enzymes activity cleared that Alkaline phosphatase (ALP) increased in the oleic, stearic and linoleic acids treatments (33.23, 108.6 and 51.24\%, respectively) and Glutamic oxaloacetic transminase (GOT) activity was increased by $22.35 \%$ in stearic acid treatment ; while it decreased in case of oleic and linoleic acids treatments (-35.53 and $-23.71 \%$, respectively). Glutamic pyruvic transminase (GPT) was decreased $(-38.59 \%)$ in the stearic acid treatment while it increased slightly in oleic and linoleic acids treatments (8.48 \& $12.79 \%$, respectively) when compared with control.

Key Words: Fatty acids, oleic acid, stearic acid, linoleic acid, biochemical studies, enzymes activity, Spiny bollworm, SBW,

Earias insulana.
\end{abstract}

\section{INTRODUCTION}

The spiny bollworm Earias insulana (Boisd.) is known as serious pest of cotton , okra and other malvaceous plants in North Africa , India ,Pakistan and other countries of the Mediterranean basin, as well as in Asia and Africa (Abida et al., 2004). E. insulana larvae feed on cotton terminal shoots, flowers, buds and bolls, destroying fiber and consuming seeds and causes significant damage in cotton crop. Since the 1990s the spiny bollworm range has broadened and the incidence of damage has 
increased. It is currently considered a leading cotton pest in southern and eastern Spain (Pérez-Guerrero et al., 2011).

For the control of this insect in the field, a number of insecticides belonging to different groups have been effective but the continuous use may result the development of resistance. Recently, plant oil extracts are considered one of the most control methods that environmentally safe, less hazardous to non-target organisms, easy for preparation, inexpensive and can be applied by using techniques more suitable for developing countries with lower operating costs (WHO, 1992). The potency of botanical fatty acids was reported by Yousef et al., 2013, Ramos-López et al., 2012 and Yousef and Moustafa 2013.

Oleic acid is a monounsaturated fatty acid with a symmetrically placed double bond. Its IUPAC name is cis-9-octadecenoic acid; its lipid shorthand name is 18:1 cis9. Oleic acid (omega-9) is a fatty acid found in animal and vegetable oils, such as olive oil (extra virgin or virgin), olives, avocados, almonds, peanuts, sesame oil, pecans, pistachio nuts, cashews, hazelnuts, macadamia nuts (Thailand, 2005).

Stearic acid (octadecanoic acid) is a saturated fatty acid derived from animal and vegetable fats and oils. In Malaysia, it is mainly produced by the oleochemical (palm oil) industry and it has been the primary fatty acid commodity for many years (MPOB, 2003).

Conjugated linoleic acid is a mixture of positional and geometrical isomers of linoleic acid (C18:2, cis-9, cis-12), an essential fatty acid for human and animals (Eulitz et al., 1999).

The aim of the present investigation was to study the toxic and biochemical effects of three different $\mathrm{C} 18$ fatty acids (oleic, stearic and linoleic acid) against Earias insulana (Boisd.) in the laboratory. The relation between the presence or absence and number of double bond in the compounds under studying and the activity of these substances against $E$. insulana was mentioned here.

\section{MATERIALS AND METHODS}

\section{Chemicals:}

Three fatty acids (oleic, stearic and linoleic acids) were used in the present study: Oleic acid was obtained from Techno Pharmchem, Bahadurgarh, Haryana (India). 


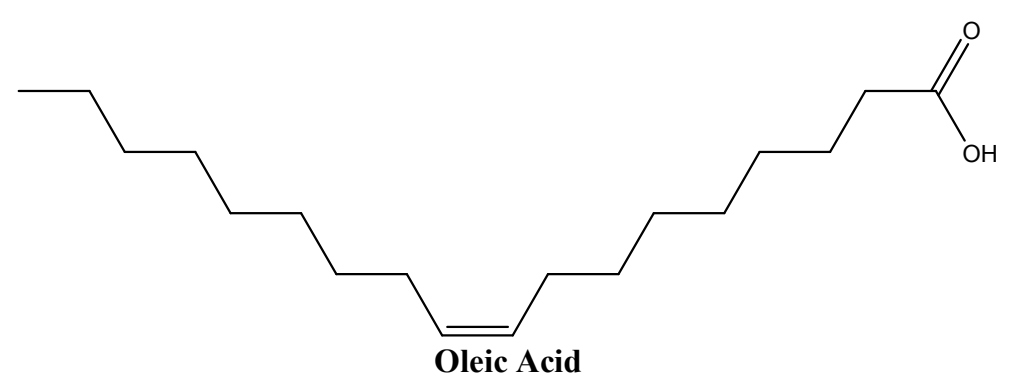

Stearic acid was obtained from Technogene corp. Dokki, Cairo, Egypt.

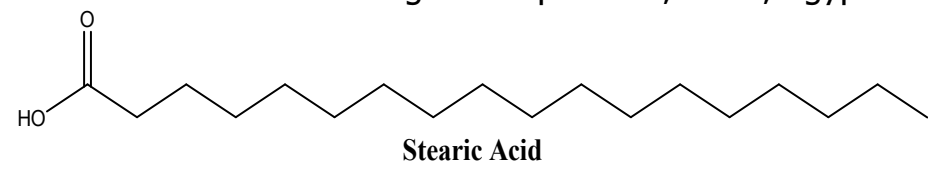

Linoleic acid was purchased from ABCR GmbH \& Co KG, Im Schlehert 10, 76187 Karlsruhe, Germany.

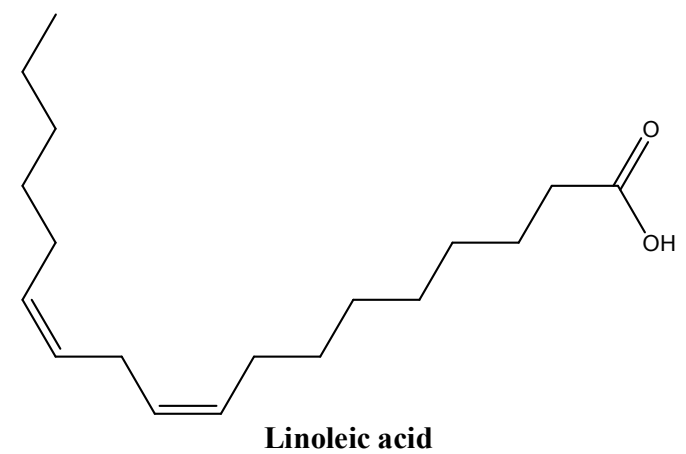

\section{Insect culture:}

1- Newly-hatched larvae of the spiny bollworm were obtained from the Bollworm Research Department, Plant Protection Research Institute, Dokki, Giza, Egypt. Rearing conditions were controlled at $27^{\circ} \mathrm{C} \pm 2$ and $70-85 \% \mathrm{RH}$. The newly hatched larvae fed on semi-artificial diet as described previously by (Rashad \& Ammar, 1985).

2-

\section{Toxicity assay:}

Serial concentrations of $10,5,2.5,1.25$, and 0.625 (g fatty acid/ $100 \mathrm{~g}$ diet) were prepared. Thirty newly hatched larvae were transferred individually to the surface of the diet using a soft brush kept in glass tubes $(2 \times 7.0 \mathrm{~cm})$ capped with cotton stopper to study the response of the newly hatched larvae of SBW. The larvae were fed on the treated diet for $48 \mathrm{~h}$, and then transferred to feed on untreated diet. Similar number of larvae was transferred into untreated diet and used as control. All tubes were incubated at $27 \pm 2^{\circ} \mathrm{C}$ and $70-85 \% \mathrm{RH}$. Mortality was recorded after 24,48 and 72 hrs. after larval feeding. Mortality percentages were corrected according to Abbott's formula (1925) in each case.

\section{Effect of the tested fatty acids on biological parameters of $E$. insulana}

A concentration of $\mathrm{LC}_{50}$ was prepared as mentioned before, after larval transfer from the treated diet to untreated diet in the tubes were capped with cotton, 
and kept under the previous condition and inspect daily till pupation to investigate the effect of fatty acids on larval \& pupal period and larval\& pupal weight of $E$. insulana. The reduction in weight was calculated as follow: Weight reduction $=[$ (weight of control - weight of treatment) / (weight of control)] X 100.

\section{Determination of enzymes}

The enzymes were prepared as described by Amin (1998). $4^{\text {th }}$ instar larvae resulted from treated $1^{\text {st }}$ instar larvae of spiny bollworm with the $\mathrm{LC}_{50}$ concentration were homogenized in distilled water $(50 \mathrm{mg} / 1 \mathrm{ml})$. Homogenates were centrifuged at $8000 \mathrm{rpm}$ for $15 \mathrm{~min}$ at $2^{\circ} \mathrm{C}$ in a cooling centrifuge. The deposits were discarded and the supernatants, which is referred as enzymes extract, and can be stored for one week without appreciable loss of activity at $-5^{\circ} \mathrm{C}$.

Glutamic oxaloacetic transminase (GOT) and Glutamic pyruvic transminase (GPT) activities were determined colorimetrically according to the method of Reitman and Frankle (1957). Alkaline phosphatases (ALP) activities were determined according to the method described by Powell and Smith (1954). In this method, the phenol released by enzymatic hydrolysis of disodium phenylphosphate reacts with 4aminoantipyrine, and by the addition of potassium ferricyanide, the characteristic brown color is produced.

Total protein content was determined according to the method of Bradford (1976) using coomassie brilliant blue reagent. Total carbohydrates were estimated in acid extract of sample by the phenol-sulphuric acid reaction of Dubois et al., (1956). Total carbohydrate were extracted and prepared for assay according to Crompton and Birt (1967). Total lipids were estimated by the method of Knight et al., (1972) using phosphovanillin reagent prepared by dissolving of $0.6 \mathrm{gm}$ pure vanillin in $10 \mathrm{ml}$ ethanol and completed to $100 \mathrm{ml}$ with distilled water, then $400 \mathrm{ml}$ conc. Phosphoric acid were added.

\section{Statistical analysis}

The data were statistically analyzed using ANOVA and Duncan's multiple range tests (ANOVA of arcsine square root transformed percentages). Differences between the treatments were determined by Tukey's multiple range test $(P<0.05)$ (Snedecor and Cochran, 1989).

\section{RESULTS AND DISCUSSION}

Response of the $1^{\text {st }}$ instar larvae of Earias insulana (Boisd) after treatment with different concentrations of oleic acid is shown in Table (1). The $L C_{50}$ was 1.83 $\mathrm{g} / 100 \mathrm{~g}$ after 24 hours, $1.69 \mathrm{~g} / 100 \mathrm{~g}$ after 48 and 72 hours. 
Mortality (\%) of $1^{\text {st }}$ instar larvae of $E$. insulana after treatment with different concentrations of stearic acid is shown in Table (2). The $L_{50}$ was $2.08 \mathrm{~g} / 100 \mathrm{~g}$ after 24hours and $1.47 \mathrm{~g} / 100 \mathrm{~g}$ after 48 and 72 hours.

Table 1. Toxic effect of oleic acid against $1^{\text {st }}$ instar larvae of $E$. insulana

\begin{tabular}{|c|c|c|c|}
\hline \multirow{2}{*}{ Oleic acid } & \multicolumn{3}{|c|}{$\%$ Corrected mortality at intervals of time in hours } \\
\cline { 2 - 4 } & $24 \mathrm{hrs}$ & $48 \mathrm{hrs}$ & $72 \mathrm{hrs}$ \\
\hline $10.00[\mathrm{~g} / 100 \mathrm{~g}$ diet $]$ & $83.93^{\mathrm{a}}$ & $87.41^{\mathrm{a}}$ & $87.41^{\mathrm{a}}$ \\
\hline $5.00[\mathrm{~g} / 100 \mathrm{~g}$ diet $]$ & $72.15^{\mathrm{b}}$ & $75.77^{\mathrm{b}}$ & $75.77^{\mathrm{b}}$ \\
\hline $2.5[\mathrm{~g} / 100 \mathrm{~g}$ diet $]$ & $57.16^{\mathrm{c}}$ & $59.99^{\mathrm{c}}$ & $59.99^{\mathrm{c}}$ \\
\hline $1.25[\mathrm{~g} / 100 \mathrm{~g}$ diet $]$ & $41.24^{\mathrm{d}}$ & $42.25^{\mathrm{d}}$ & $42.25^{\mathrm{d}}$ \\
\hline $0.625[\mathrm{~g} / 100 \mathrm{~g}$ diet $]$ & $26.02^{\mathrm{e}}$ & $26.58^{\mathrm{e}}$ & $26.58^{\mathrm{e}}$ \\
\hline Control & 0 & 0 & 0 \\
\hline$L C 50$ [g/ $100 \mathrm{~g}$ diet $]$ & 1.83 & 1.69 & 1.69 \\
\hline Slope & $1.34 \pm 0.27$ & $1.49 \pm 0.28$ & $1.49 \pm 0.28$ \\
\hline
\end{tabular}

Values within the same row having the same letters are not significant different (ANOVA, Duncan's multiple range tests, $\mathrm{P}<0.05$ )

Table 2. Toxic effect of steric acid against $1^{\text {st }}$ instar larvae of $E$. insulana

\begin{tabular}{|c|c|c|c|}
\hline \multirow{2}{*}{ Stearic acid } & \multicolumn{3}{|c|}{$\%$ Corrected mortality at intervals of time in hours } \\
\cline { 2 - 4 } & $24 \mathrm{hrs}$ & $48 \mathrm{hrs}$ & $72 \mathrm{hrs}$ \\
\hline $10.00[\mathrm{~g} / 100 \mathrm{~g} \mathrm{diet}]$ & $72.94^{\mathrm{a}}$ & $80.84^{\mathrm{a}}$ & $80.84^{\mathrm{a}}$ \\
\hline $5.00[\mathrm{~g} / 100 \mathrm{~g} \mathrm{diet}]$ & $63.34^{\mathrm{b}}$ & $71.10^{\mathrm{b}}$ & $71.10^{\mathrm{b}}$ \\
\hline $2.5[\mathrm{~g} / 100 \mathrm{~g}$ diet $]$ & $52.83^{\mathrm{c}}$ & $59.50^{\mathrm{c}}$ & $59.50^{\mathrm{c}}$ \\
\hline $1.25[\mathrm{~g} / 100 \mathrm{~g} \mathrm{diet}]$ & $42.11^{\mathrm{d}}$ & $46.99^{\mathrm{d}}$ & $46.99^{\mathrm{d}}$ \\
\hline $0.625[\mathrm{~g} / 100 \mathrm{~g}$ diet $]$ & $31.96^{\mathrm{e}}$ & $34.78^{\mathrm{e}}$ & $34.78^{\mathrm{e}}$ \\
\hline Control & 0 & 0 & 0 \\
\hline $\mathrm{LC}$ [50 [g/ $100 \mathrm{~g}$ diet $]$ & 2.08 & 1.475 & 1.475 \\
\hline Slope & $0.89 \pm 0.25$ & $1.05 \pm 0.26$ & $1.05 \pm 0.26$ \\
\hline
\end{tabular}

Values within the same row having the same letters are not significant different (ANOVA, Duncan's multiple range tests, $\mathrm{P}<0.05)$.

Effect of linoleic acid against $1^{\text {st }}$ instar larvae of $E$. insulana is presented in Table (3). The $\mathrm{LC}_{50}$ value was $6.88 \mathrm{~g} / 100 \mathrm{~g}$ after 24 hours and $6.07 \mathrm{~g} / 100 \mathrm{~g}$ after 72 hours.

From tables $(1,2 \& 3)$ it's obviously noticed that there was no difference between $\%$ mortality after $48 \mathrm{hr}$ or $72 \mathrm{hr}$ from treating $1^{\text {st }}$ instar larvae of SBW with different concentrations of the tested fatty acids.

Potency of botanical fatty acids was reported by Yousef et al., (2013) showed that linoleic acid proved high toxic effect on the $2^{\text {nd }}$ and $4^{\text {th }}$ instar larvae of $S$. littoralis, with LC 50 values of 4.78 and $9.11 \mathrm{~g} / 100 \mathrm{~mL}$, respectively. And, Ramos-López et al., 
(2012) described, linoleic acids has insecticidal activities against Spodoptera frugiperda. Also, Perumalsamy et al., (2015) studied the toxicity of oleic acid and linoleic acid toward $C$. pipiens and A.aegypti larvae. They concluded that structure activity relationship indicates that the degree of saturation, the side chain length and the geometric isomerism of fatty acids appear to play a role in determining the fatty acid toxicity.

Table 3. Toxic effect of linoleic acid against $1^{\text {st }}$ instar larvae of $E$. insulana

\begin{tabular}{|c|c|c|c|}
\hline \multirow{2}{*}{ Linoleic acid } & \multicolumn{3}{|c|}{ \% Corrected mortality at intervals of time in hours } \\
\cline { 2 - 4 } & $24 \mathrm{hrs}$ & $48 \mathrm{hrs}$ & $72 \mathrm{hrs}$ \\
\hline $10.00[\mathrm{~g} / 100 \mathrm{~g}$ diet $]$ & $56.54^{\mathrm{a}}$ & $58.89^{\mathrm{a}}$ & $58.89^{\mathrm{a}}$ \\
\hline $5.00[\mathrm{~g} / 100 \mathrm{~g}$ diet $]$ & $47.51^{\mathrm{b}}$ & $48.85^{\mathrm{b}}$ & $48.85^{\mathrm{b}}$ \\
\hline $2.5[\mathrm{~g} / 100 \mathrm{~g}$ diet $]$ & $38.70^{\mathrm{c}}$ & $38.99^{\mathrm{c}}$ & $38.99^{\mathrm{c}}$ \\
\hline $1.25[\mathrm{~g} / 100 \mathrm{~g}$ diet $]$ & $29.96^{\mathrm{d}}$ & $30.57^{\mathrm{d}}$ & $30.57^{\mathrm{d}}$ \\
\hline Control & 0 & 0 & 0 \\
\hline $\mathrm{LC} C_{50}[\mathrm{~g} / 100 \mathrm{~g}$ diet $]$ & 6.88 & 6.07 & 6.07 \\
\hline Slope & $0.78 \pm 0.35$ & $0.87 \pm 0.35$ & $0.87 \pm 0.35$ \\
\hline
\end{tabular}

Values within the same row having the same letters are not significant different (ANOVA, Duncan's multiple range tests, $\mathrm{P}<0.05)$.

The larval and pupal duration and weight after treatment of the newly hatched larvae with the LC 50 concentration of oleic acid, stearic acid and linoleic acid were shown in table (4). The average of larval period treated with oleic, stearic and linoleic acid recorded 24.47, 18.93 and 22.00 days, respectively. It was insignificantly differing than the control (15.06 days). On the other hand, the use of oleic acid, stearic acid and linoleic acid prolonged the pupal period (10.47, 10.19 and 11.00 days), respectively compared to (8.06 days) in the control.

In addition, the average larval weight decreased to reach $0.018 \mathrm{~g} /$ larvae in oleic acid and linoleic acid treatments, respectively, and $0.020 \mathrm{~g} / \mathrm{larvae}$ in stearic acid treatment, compared to $0.067 \mathrm{~g} /$ larva in the control. Reduction percentage in the larval weight attained $73.13 \%$ when treated with oleic acid and linoleic acid, respectively and $70.15 \%$ when treated with stearic acid. Also, the pupal weight decreased in all treatments than in the control. The percentage of pupal weight reduction was $36.17 \%, 40.42 \%$ and $38.30 \%$ for those treated in larval stage with oleic acid, stearic acid and linoleic acid, respectively. 
Table 4. Effect of sub-lethal concentration of oleic, stearic and linoleic acid on some biological parameters of $E$. insulana.

\begin{tabular}{|c|c|c|c|c|c|c|}
\hline \multirow[b]{2}{*}{ Treatments } & \multicolumn{3}{|c|}{ Larval stage } & \multicolumn{3}{|c|}{ Pupal stage } \\
\hline & $\begin{array}{l}\text { Duration days } \\
\text { ( Mean } \pm \text { SE) }\end{array}$ & Weight (g) & $\begin{array}{l}\text { W.R } \\
\% *\end{array}$ & $\begin{array}{c}\text { Pupal duration } \\
\text { (days) } \\
\text { ( Mean } \pm \text { SE) }\end{array}$ & Weight (g) & $\begin{array}{c}\text { W.R\% } \\
\quad *\end{array}$ \\
\hline Oleic acid & $24.47^{a} \pm 5.10$ & $0.018^{\mathrm{c}} \pm 0.0001$ & 73.13 & $10.47^{a} \pm 1.34$ & $0.030^{\mathrm{b}} \pm 0.005$ & 36.17 \\
\hline Stearic acid & $18.93^{c} \pm 3.61$ & $0.020^{b} \pm 0.003$ & 70.15 & $10.19^{a} \pm 2.08$ & $0.028^{c} \pm 0.003$ & 40.42 \\
\hline Linoleic acid & $22.00^{\mathrm{b}} \pm 5.8$ & $0.018^{b c} \pm 0.001$ & 73.13 & $11.00^{\mathrm{a}} \pm 1.00$ & $0.029^{c} \pm 0.004$ & 38.30 \\
\hline Control & $15.06^{\mathrm{d}} \pm 5.2$ & $0.067^{a} \pm 0.17$ & 0.00 & $8.06^{b} \pm 1.73$ & $0.047^{a} \pm 0.006$ & 0.00 \\
\hline F value & $101.32^{* * *}$ & $1016.32^{* * *}$ & & $5.89^{*}$ & $158.56^{* * *}$ & \\
\hline LSD & 1.29 & 0.0024 & & 1.82 & 0.0022 & \\
\hline
\end{tabular}

* W.R =Weight Reduction

Values within the same row having the same letters are not significant different (ANOVA, Duncan's multiple range tests, $\mathrm{P}<0.05)$.

Results in Table (5) showed the changes in the total contents of protein, carbohydrate and lipids and the activity enzymes of Alkaline phosphatase (ALP), Glutamic oxaloacetic transminase (GOT) and Glutamic pyruvic transminase (GPT), from the $4^{\text {th }}$ instar larvae of $E$. insulana fed as newly hatched larvae on artificial diet mixed with $\mathrm{LC}_{50}$ concentration of the tested fatty acids. Oleic acid and stearic acid reduced the total protein content to -28.49 and $-1.96 \%$, respectively compared with the control larvae. While, the total protein content increased to $46.93 \%$ in linoleic acid treatment. The oleic acid and stearic acid results are in agreement with those obtain with El-Shershaby et al., (2008) who, indicated that treatment of Spodoptera littoralis larvae by the bacterial formulation Dipel-2x resulted in negative changes in the total protein content and this may be due to bacterial toxins which led to inhibition of protein synthesis by forming a protein complex.

The total carbohydrates content of $4^{\text {th }}$ instar larvae of $E$. insulana decreased to (31.37, -6.12 and -3.42 , respectively), in oleic acid, stearic acid and linoleic acid treatments presented in table (5). Total carbohydrates and total protein are major biochemical components necessary for an organism development, growth and performance of its vital activities. 
Table 5. Effect of sub-lethal concentration of stearic, oleic and linoleic acid on the total protein, carbohydrates, lipids contents and some enzyme activities of the $4^{\text {th }}$ instar larvae of $E$. insulana

\begin{tabular}{|c|c|c|c|c|c|c|c|c|}
\hline \multirow[b]{2}{*}{ Enzyme } & $\begin{array}{l}\text { Oleic acid } \\
\text { Mean } \pm S . E\end{array}$ & $\begin{array}{l}\text { chang } \\
e \%\end{array}$ & $\begin{array}{l}\text { Stearic acid } \\
\text { Mean } \pm \text { S.E }\end{array}$ & $\begin{array}{c}\text { change } \\
\%\end{array}$ & $\begin{array}{l}\text { Linoleic acid } \\
\text { Mean } \pm S . E\end{array}$ & $\begin{array}{c}\text { change } \\
\%\end{array}$ & $\begin{array}{l}\text { Control } \\
\text { MeantS.E }\end{array}$ & $\begin{array}{l}\text { chang } \\
e \%\end{array}$ \\
\hline & & & & & & & & \\
\hline Total Protein(mg/g.but) & $97 \div \pm 2.516$ & -28.49 & $133^{a} \pm 2.516$ & -1.96 & $199.33^{\circ} \pm 2.19$ & 46.93 & $135.66^{\circ} \pm 3.38$ & . \\
\hline $\begin{array}{l}\text { Total Carbohydrates } \\
\text { (mg/g.bwt) }\end{array}$ & $6.63^{b} \pm 0.233$ & -31.37 & $9.00^{6} \pm 0.22$ & -6.21 & $9.33^{a} \pm 0.34$ & -3.42 & $9.66^{6} \pm 0.202$ & . \\
\hline Total Lipids(mg/g.bwt) & $5.366^{6} \pm 0.12$ & -21.09 & $4.40 \div 0.15$ & -35.29 & $5.8^{6} \pm 0.18$ & -14.26 & $6.80^{\circ} \pm 0.11$ & - \\
\hline $\begin{array}{l}\text { Alkaline phosphatase } \\
\text { (U/g.b.wt) }\end{array}$ & $35.03^{b} \pm 0.82$ & 33.23 & $54.80^{a} \pm 3.17$ & 108.6 & $39.73^{b} \pm 1.45$ & 51.24 & $26.27 \pm 1.54$ & $\cdot$ \\
\hline $\operatorname{GOT}(U / g, b, w t)$ & $75.00^{d} \pm 2.89$ & -35.53 & $142,33^{a} \pm 3.71$ & 22.35 & $88.67 \pm 0.88$ & -23.71 & $116.33^{b} \pm 3.28$ & \\
\hline GPT (U/g.b.wt) & $69.83^{30} \pm 1.92$ & 8.48 & $39.53 \pm 1.63$ & -38.59 & $72,60^{0} \pm 1,30$ & 12.79 & $64.37^{\circ} \pm 1.85$ & . \\
\hline
\end{tabular}

Values are mean $\pm \mathrm{SE}$ of three replicates.

Values within the same row having the same letters are not significant different (ANOVA, Duncan's multiple range tests, $\mathrm{P}<0.05)$

Change $(\%)=[($ Mean values of treatment- Mean values of control $) /$ Mean values of control $] \times 100$

A positive value means increase in enzyme activity and the negative values means a decrease.

In insects' bodies carbohydrates are of vital importance since they can be utilized by the insect body for production of energy or conversion to lipids or proteins. The same results were found by Bennet and Shotwell (1972) who reported a rapid reduction in the haemolymph carbohydrates following injection of bacteria into some insect species, the Japanese beetle larvae Popillia japonica.

Also in table (5), total lipid content was decreased significantly in the three treatments of oleic acid, stearic acid and linoleic acid compared with the control, where the reduction were $(-21.09,-35.29$ and -14.26 , respectively). Lipids in insects tissue is in the form of glycerides, predominantly triglycerides in the fat body to provide reserves of energy, so the reduction in the total carbohydrate and lipids mean reduction in the energy reserves and the amount of body weight. It is well known that stored lipids are most important and convenient reservoirs of metabolic energy, which 
fulfill prolonged energy demand in insects in stress. Physiologically lipids play an important role in insect survival. Once lipid metabolism is inhibited most of the normal physiological activities of insect get obstructed that result in to death (Lohar and Wright, 1993).

In case of alkaline phosphatase activity (ALP) there was a significant increase in the three treatments of fatty acids relative to control that were reported in table (5). The percentages of increase ALP activity were 33.23, 108.6 and 51.24 for the oleic, stearic and linoleic acid, respectively. Phosphatases are defined as enzymes hydrolyzing any phosphorus ester or anhydride bond (O' Brien, 1967). Acid and alkaline phosphatase has been studied as enzymes significant in detoxification. Zhao et al. (2017) suggested that ALP2 is involved in the mechanism of action of Cry2Aa in $H$. armigera and may play important functional roles in the toxicity of the Cry2Aa toxin.

Table (5) show that Glutamic oxaloacetic transminase (GOT) activity was significantly increase with stearic acid treatment to $22.35 \%$; while a significant decrease occurred in oleic and linoleic acid treatment ( -35.53 and -23.71 , respectively).

The activity of Glutamic pyruvic transminase (GPT) was decreased significantly in the larvae treated with stearic acid to $-38.59 \%$, while it increased to 8.48 and $12.79 \%$ with oleic and linoleic acid, respectively. In this respect, Yousef and El-lakwah (2014) recorded a decrease in the content of total carbohydrates and protein contents in compared with the control larvae and activity of the enzyme GPT, GOT and ALP were decreased compared with control after $48 \mathrm{~h}$ of the $4^{\text {th }}$ instar larval of $S$. littoralis fed on Melia azedarach oil or its terpenes treated leaves. Upadhyay (2013) mentioned that in treated Rhizopertha dominica (Fabr) both GPT and GOT play an important role in protein metabolism and were inhibited by the Capparis decidua extracts. A sharp decrease or increase in the level of above enzymes effect oxygen consumption in insects (Pant and Morris, 1972). However, inhibition of phosphatase and lactic dehydrogenase level shows tissue necrosis in insects (Ishaaya and Casida, 1980). The imbalance in enzyme level indicates inhibition of important metabolic pathways (Srinivas et al., 2004).

Results in the present study tabulated in tables $(1,2,3)$ and $\mathrm{LC}_{50}$ values for all tested fatty acids against the SBW cleared that the saturated fatty acid (stearic acid) caused the highest mortality percentages for the treated larvae after 24 hrs, followed by oleic acid (the fatty acid with one double bond) and the latest one linoleic acid (the fatty acid which contains two double bonds). Generally, the saturated fatty 
acid was more toxic than the two unsaturated fatty acids and as the unsaturation increased the toxic effect decreased.

In conclusion, the three $\mathrm{C} 18$ fatty acids (oleic, stearic, and linoleic acid) caused high mortality in Earias insulana (Boisd.) at the different concentrations used. The $\mathrm{LC}_{50}$ concentration of the three acids prolonged larval and pupal periods and reduced its body weight, also, changed the level of lipid, carbohydrates, protein contents and the ALP, GOT and GPT activities. This indicated the high toxicity of the three fatty acids toward the SBW.

\section{REFERENCES}

1. Abbott, W.S.A. 1925. Method for computing the effectiveness of an insecticide. J. Econ. Entomol. 18: 265.

2. Abida, N., Cheema, G.M., Shoaib, F., Saleem, M.A. 2004. Resistance of different cotton cultivars to chewing insect pests. Pak. Entomol. 26:81-85.

3. Amin, T.R. 1998. Biochemical and physiological studies of some insect growth regulators on the cotton leafworm, spodoptera littoralis (Boisd.). Ph.D. Thesis, Faculty of science, Cairo Univ.

4. Bennett, G.A. and Shotwell, O.L. 1972. Heamolymph lipids of healthy and diseased Japanese beetle larvae. J. Insect Physiol., 18: 53- 62.

5. Bradford, M.M. 1976. "A rapid and sensitive method for the quantitation of microgram quantities of protein utilizing the principle of protein-dye binding". Anal. Biochem., 5: 248-254.

6. Crompton, M. and Birt, L.M. 1967. Changes in the amounts of carbohydrate, phosphagen, and related copounds during the metamorphosis of the blowfly, Lucilia cuprina. J. Insect physiol., 13:1575-1595.

7. Dubois, M. Gilles, K.A. Rebers, P.A. and Smith, F. 1956. Colorimetric method for determination of sugars and related substances. Anal. Chem., 28:350-356.

8. El-Shershaby, M.; Farag, N.A. and Ahmed, A.A. 2008. Impact of Bacillus thurigiensis on protein conten and enzymes activity of Spodoptera littoralis, Res. J. Agricul. And Biol. Sci., 4 (6): 861-865.

9. Eulitz, K., Yurawecz, M.P., Sehat, N., Fritsche, J., Roach, J.A.G., Mossoba, M.M., Kramer, J.K.G., Adlof, R.O., Ku, Y. 1999. Preparation, separation, and confirmation of the eight geometrical cis/trans conjugated linoleic acid isomers 8, 10-through 11, 1318:2. Lipids, 34: 873-877.

10. Ishaaya, I. and J.E. Casida. 1980. Properties and toxicological significance of esterase hydrolyzing permethrin and cypermethrin in Trichoplusiani larval gut and integument, Pest Biochem. Physiol., 14: 178-184. 
11. Knight, J.A.; S. Anderson and J.M. Rawle. 1972. Chemical basis of the sulfo-phosphovanillin reaction for estimating total serum lipids .Clin. Chem., V.18:199-202.

12. Lohar, M.K. and Wright, D.J. 1993. Changes in the lipid content in heamolymph, fat body and oocytes of Malathion treated Tenebrio molitor L. adult females Pakistan J Zool, 25: 57-60.

13. MPOB. 2003. Malaysian Oil Palm Statistics 2002, 22nd ed, pp 56. Malaysian Palm Oil Board, Malaysia.

14. O'Brien, R. D. 1967. Insecticides - action and metabolism. Academic Press New York \& London.

15. Pant, R. and I.D. Morris. 1972. Variation in glycogen, total free sugars, protein, alkaline and acid phosphatases, citrate and inorganic phosphorus level in fat body of Philosamiaricini (Eri-Silkworm) during development, J. Biochem., 71(1): 1-8.

16. Pérez-Guerrero S., Aldebis H. K., Vargas-Osuna E. 2011. Toxicity of several dendotoxins of Bacillus thuringiensis against the cotton pest Earias insulana (Lepidoptera: Noctuidae). Crop Protection, 30: 1024-1027.

17. Perumalsamy, H.; Jang, M.J.; Kim, J.R.; Kadarkarai, M. and Ahn, Y. 2015. Larvicidal activity and possible mode of action of four flavonoids and two fatty acids identified in Millettia pinnata seed toward three mosquito Species. Parasites \& Vectors. 8:237.

18. Powell, M.E.A. and Smith, M.J.H. 1954. The determination of serum acid and alkaline phosphate activity with 4-amino antipyrine. Amer. J. Clin. Pathol., 7: 245-248.

19. Ramos-López, M. A.; González-Chávez, M. M.; Cárdenas-Ortega, N. C.; ZavalaSánchez, M. A.; and G. S. Pérez. 2012. Activity of the main fatty acid components of the hexane leaf extract of Ricinus communis against Spodoptera frugiperda. Afri. J. Biotechnol. 11: 4274-4278.

20. Rashad, M.A. and Ammar, E.D. 1985. Mass rearing of the spiny bollworm, Earias insulana (Bosid) on semi artificial diet. Bull. Soc. Ent. Egypt, 65:239-44.

21. Reitman, S. and Frankel, S. 1957. Colourimetic method for aspartate and alanine transaminases. Am. J. Clin. Pathol., 28:56.

22. Snedecor G. W. and Cochran W. G. 1989. Statistical Methods, 8th ed. Iowa State University Press, Ames, IA, USA.

23. Srinivas, R.; Udikeri S.S., Jayalakshmi S.K. and Srreramulu K. 2004. Identification of factors responsible for insecticide resistance in Helicoverpaarmigera (Hubner), Comp. Biochem. Physiol., 137(3): 261-269.

24. Thailand, B. 2005. Oleic Acid - The Anti-Breast Cancer Component in Olive Oil. AU J.T. $9(2): 75-78$. 
25. Upadhyay R. K. 2013. Capparisdecidua Induced Toxicity, Biochemical and Enzymatic Alterations in Rhizoperthadominica (Fabr.) (Coleoptera: Bostrichidae). World Journal of Zoology 8 (3): 256-266.

26. WHO 1992. Fourteenth Report of the WHO Expert Committee on Vector Biology and Control, Safe Use of Pesticides. Technical Report Series No. 813, World Health Organization, Geneva, Switzerland.

27. Yousef, H. and EL-Lakwah, S. F. 2014. Effects of Melia azedarach ripe fruit extract on some enzyme activities of the cotton leafworm Spodoptera littoralis (Boisd.). Egyptian Journal of Biological Pest Control, 24(2):315-320.

28. Yousef, H., EL-Lakwah, S. F. and Y. A. El-Sayed. 2013. Insecticidal activity of linoleic acid against Spodoptera littoralis (Boisd.). Egypt. J. Agric. Res., 91 (2): 573-580.

29. Yousef , H. and Moustafa, Z. Hemat. 2013. Toxic Effect of Oleic Acid and Ripe Fruit Oil of Melia azedarach on Pectinophora gossypiella (Saunders) (Lepidoptera: Gelechiidae). Egyptian Journal of Biological Pest Control, 23(2):309-313.

30. Zhao, M.; Yuan, X.; Wei, J.; Zhang,W.; Wang, B.; Khaing, M. M. and Liang, G. 2017. Functional roles of cadherin, aminopeptidase- $N$ and alkaline phosphatase from Helicoverpa armigera (Hübner) in the action mechanism of Bacillus thuringiensis Cry2Aa. Sci. Rep. 7, 46555; doi: 10.1038/srep46555. 


\title{
النشاط البيوكيميائى والسام للأحماض الدهنية ضد دودة اللوز الثوكية
}

\section{همت زكريا محمد مصطفى'، هبه يوسف 'بو سهير فيصل اللقوه'}

\author{
' معهد بحوث وقاية النباتات، مركز البحوث الزراعية، الجبزة، مصر. \\ كَقسم الكيمياء، كلية العلوم والفنون، جامعة جده، المملكة العربية السعودية.
}

تمت دراسة نشاط ثلاثة أحماض دهنية (اوليك- سنتيكيك- لينوليك) على يرقات العمر

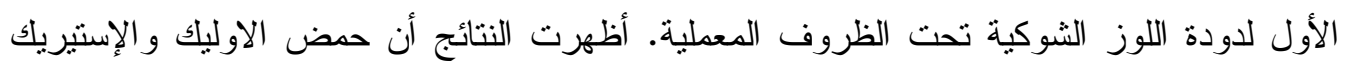

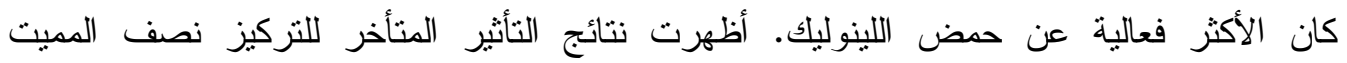

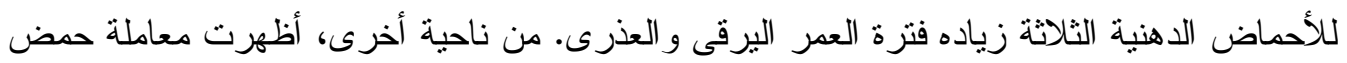

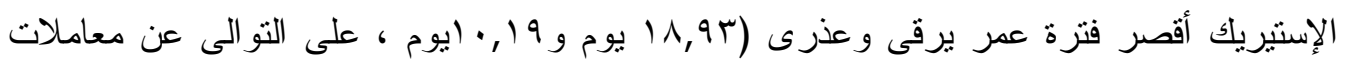

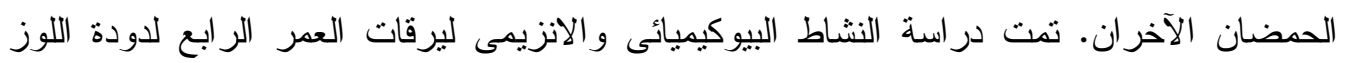

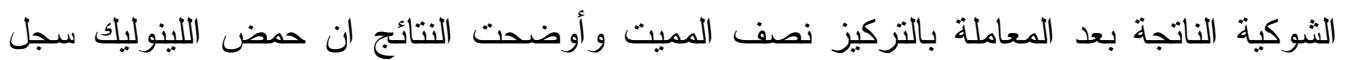

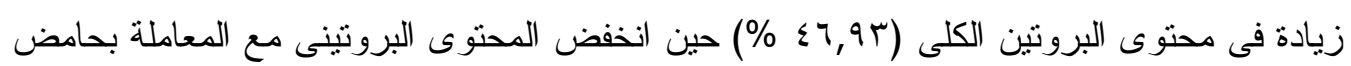

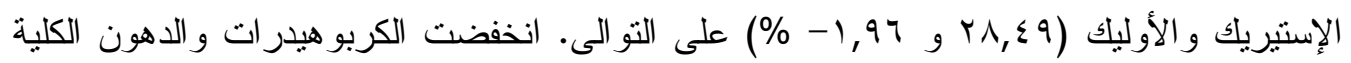

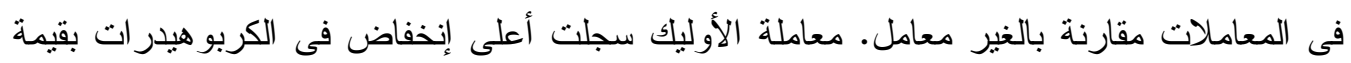

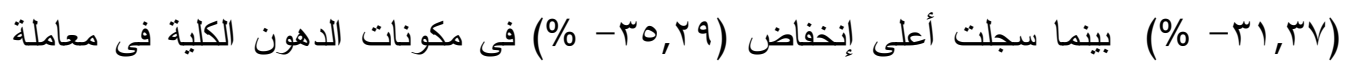
الاستيريك ـ أيضا أظهر النشاط الإنزيمى زياده نشاط إنزيم ALP لحمض الأوليك ، الإستيريك و

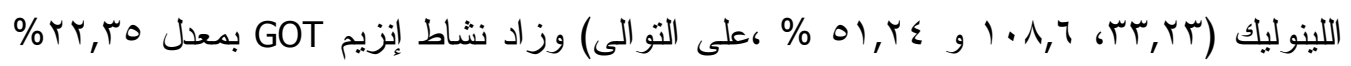

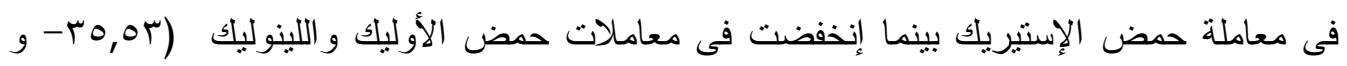
معامات

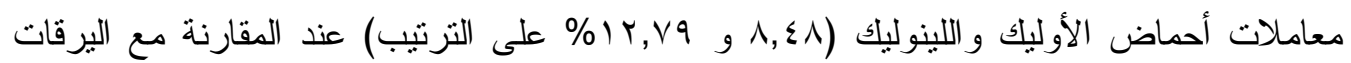

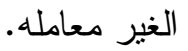

